\section{EUROPEAN \\ ASSOCIATION \\ FOR THE STUDY OF \\ DIABETES}

ASSOCIATION EUROPÉENNE

POUR L'ÉTUDE

DU DIABÈTE

\section{EUROPÄISCHE \\ GESELLSCHAFT FÜR \\ DIABETOLOGIE}

\title{
ORGANISATION SECTION
}

President: $\quad$ P. Lefèbvre, Liege (retires 1992)

Vice-Presidents: M.R. Taskinen, Helsinki (retires 1991)

E. O. Balasse, Brussels (retires 1990)

Past President: P. Freychet, Nice

Hon. Secretary: R. Landgraf, Munich (retires 1991)

Hon. Treasurer: J.D. Ward, Sheffield (retires 1992)

\author{
DIABETOLOGIA: \\ Editor in Chief: C. Hellerström, Uppsala \\ (1989-1992) \\ Executive Director: V.Jörgens \\ Administrator: C.L.Tripp \\ Secretariat: $\quad$ Auf'm Hennekamp 32 \\ 4000 Düsseldorf 1 \\ West Germany
}

The Council comprises the Officers above and the following members:

Term expiring 1990
M. Damjanova, Sofia
B. Persson, Stockholm
P. Vague, Marseille
C. Zoupas, Athens

The Chairman and Secretary of the Postgraduate Education Sub-Committee (J.-P. Assal and P.D. Home) are members ex-officio.
Term expiring 1992

E. Erkelens, Utrecht

U. Keller, Basel

P. Segal, Tel Hashomer

G. Tomkin, Dublin

\section{HONORARY MEMBERS}

W. Gepts, Brussels - J. G. L. Jackson, London - R. Levine, Duarte - R. Luft, Stockholm - K. Lundbaek, Aarhus -

A. Marble, Boston-K. Oberdisse, Düsseldorf-J.L. Rodriguez-Minon, Madrid -E. von Wasielewski, Munich

\section{SUPPORTING MEMBERS}

Ames Division, Slough, UK - Bayer AG, Leverkusen, West Germany-Becton-Dickinson Europe, Meylan, France-Boehringer Mannheim GmbH, Mannheim, West Germany - Hoechst A G, Frankfurt, West Germany - Hoechst, Italia SpA, Milan, Italy - Hypoguard Ltd, Woodbridge, UK Lifescan Inc., Mountain View, California, USA - Novo-Nordisk a/s, Bagsvaerd, Denmark - Group de Recherches Servier, Neuilly-sur-Seine, France The Upjohn Company, Kalamazoo, Michigan, USA

\section{ASSOCIATE MEMBERS}

Farmigea SpA, Pisa, Italy - Orion Pharmaceutica, Espoo, Finland - Owen Mumford Ltd, Oxford, UK - Sandoz AG, Basel, Switzerland

\section{FUTURE MEETINGS}

10-14 September 1990: Copenhagen, Denmark 10-14 September 1991: Dublin, Ireland

1992: Prague, Czechoslovakia; 1993: Istanbul, Turkey; 1994: Düsseldorf, West Germany

\section{Announcements}

\section{Chicago Satellite Symposium of the International Congress of Fibrinolysis - Thromboembolic Disorders in Diabetes Mellitus: Risk Factors and Pathogenesis}

This symposium will be held on August 3,1990 at the Drake Hotel in Chicago, Illinois, USA. This open forum will address some of the key issues in the pathophysiology and treatment of diabetes. Some of the newer information on the fibrinolytic system impairment in diabetes with particular reference to PAI and T-PA regulation will be presented in an integrated fashion. Newer therapy will also be discussed. For further information, please contact: Dr. H. Kwaan, VA Lakeside Hospital, 333 E.Huron, Room 804, Chicago, IL 60611, USA. Tel.: $312-664-4718$ or Dr. J.Fareed, Loyola Univ. Med. Ctr.,
2160 S. First Ave., Maywood, IL 60153, USA. Tel.: 708-216-3262 or Fax 708-216-6660.

\section{International Symposium on Multiple Risk Factors in Cardiovascular Disease}

This symposium will be held from December 10-12, 1990 in Washington, USA. For further information please contact: The Organizing Secretariat, c/o Dr. M. G. Horning, Baylor College of Medicine, One Baylor Plaza, Houston, Texas 77030, USA. Tel.: (713) 797.0401, Fax (713) 796.8853. For Europe: Fondazione Giovanni Lorenzini, Milan, Italy. Tel.: (02) 78.38.68/76.00.22.67, Fax:(02) 78.15.11. 